\title{
Yield Performance of Faba Bean Cultivars under Different Environmental Conditions in Greece
}

\author{
Agapi KATSOULIERI ${ }^{1}$, Panayiota PAPASTYLIANOU*¹, Ilias TRAVLOS ${ }^{1}$, Dimitrios VLACHOSTERGIOS ${ }^{2}$, \\ Evangelia TIGKA ${ }^{2}$, Anastasia KARGIOTIDOU ${ }^{2}$, Christos DORDAS ${ }^{3}$, Emmanouil PRATSINAKIS ${ }^{3}$, Eleni \\ TANI $^{4}$, Demosthenis CHACHALIS ${ }^{5}$, Dimitrios BILALIS ${ }^{1}$
}
${ }^{1}$ Agricultural University of Athens, School of Plant Sciences, Department of Crop Science, Laboratory of Agronomy, 75 Iera Odos St., 11855 Athens, Greece
${ }^{2}$ Hellenic Agricultural Organization Demeter, Institute of Industrial and Forage Crops, 1 Theophrastou St., 41335 Larissa, Greece
${ }^{3}$ Aristotle University of Thessaloniki, School of Agriculture, Laboratory of Agronomy, 54124
Thessaloniki, Greece
${ }^{4}$ Agricultural University of Athens, School of Plant Sciences, Department of Crop Science, Laboratory of Plant Breeding, 75 Iera Odos St., 11855 Athens, Greece
${ }^{5}$ Benaki Phytopathological Institute, 8 Stefanou Delta St., 14561 Athens, Greece
*corresponding author: ppapastyl@aua.gr

BulletinUASVM Horticulture 77(2) / 2020

Print ISSN 1843-5254, Electronic ISSN 1843-5394

DOI:10.15835/buasvmcn-hort: 2020.0016

\begin{abstract}
Faba bean is an important grain legume, grown for human consumption and animal feed and can be used as an alternative to soybean protein. Drought and heat strongly influence faba bean growth and production, especially in flowering and pod development stages. The aim of this study was to determine the response of six cultivars to different environmental conditions during the 2018-2019 growing season. Four inbred lines and two commercial cultivars were sown in different environments in South, Central and North Greece. At each location, a randomized complete block design with four replications was used. Different characteristics such as plant height, number of pods plant ${ }^{-1}$, number of seeds pod ${ }^{-1}$, seed yield and 1000-seed weight, were recorded. The results indicated that all traits were significantly affected by different climatic conditions and cultivars. In most cases, seed yield and 1000-seed weight decreased with increasing drought conditions in the southern site. KK10 produced higher yield and pods plant ${ }^{-1}$, especially in North and Central Greece. The late maturity cultivars, 'Polycarpe' and KK14, showed lower values for the seed traits under all locations. Multi-location trials are useful for the evaluation of new cultivars and lead to an increase in production of feedstuff directly available to farmers.
\end{abstract}

Keywords: temperature, Vicia faba L. minor, yield, yield components

\section{Introduction}

Grain legumes are an important source of protein for human consumption and animal feed. The integration of legumes into agricultural systems could reduce the current protein deficit, contribute to the sustainable improvement of the environment due to their ability to fix nitrogen and their beneficial effects in soil fertility and carbon storage, thus ensuring the sustainability of agri- food systems and food security (De Ron et al., 2017; Squire etal., 2019). Grain legumes were cultivated on $16.5 \%$ of the global arable area in 2018, producing $14.5 \%$ of the total production of all grain crops. In the European Union the corresponding figures are only $2.2 \%$ and $2.3 \%$ for the area and production respectively, with soybean, pea and faba bean as the dominant crops (FAOSTAT, 2018). In particular, soybean has become the ascendant source of plant 
proteins and European agriculture has a deficit of about $70 \%$ in high-protein requirements of which $87 \%$ is covered by imported soybean and soymeal (Watson et al., 2017). Faba bean, pea and lupins, among others, are native European legumes that can become true alternatives to soybean, given their elevated and high-quality protein content, potential human health benefits and suitability for sustainable production.

Faba bean is one of the most important cool season legume species grown on approximately 2.5 million ha globally for human consumption, animal feed and green manure purposes (FAOSTAT, 2018). It is the third legume crop cultivated in the EU, with a total area of 379,000 ha and total production 912,500 tons, after soybeans and field peas (EUROSTAT, 2018). Faba bean seed has a high protein content of $30 \%$ and can be used in ruminant, pig and poultry nutrition where it can replace soybean meal to a large extent (Crépon et al., 2010). In addition, the crop value in rotations is well known due to its high $\mathrm{N}$ fixing ability to amounts up to $200 \mathrm{~kg} \mathrm{ha}^{-1}$, for improvement of soil properties and as break-crops interrupting disease and pest cycles (Neugschwandtner et al., 2015; Robson et al., 2002).

Heat, drought, and uneven rainfall are linked to climate change and such conditions are considered major constraints to faba bean growth and production. Yield sensitive phenological stages of faba bean to abiotic stresses are flowering and pod development, with yield losses up to $50 \%$ during early pod-setting. These stages coincide with spring and early summer months under semi-arid Mediterranean conditions where high temperatures, particularly when combined with drought, leading to flower abortion, lower the number of pods and reduce seed yield (Karkanis et al., 2018; Mwanamwenge et al., 1999). However, faba bean cultivars differ widely in their responses to drought and heat stresses (Siddiqui et al., 2015).

In Greece, soybean production is very low $(2,000 \mathrm{ha})$ and the total yield was 4,300 tons, which could not meet the total demand for national consumption (ELSTAT, 2018). In fact, there is a 98\% gap between production and consumption which has created an urgent need for importation to fulfill the requirements of the local market, especially for animal feed (EUROSTAT, 2016). In order to minimize this reliance, there is an upward trend in grain legumes cultivation, especially in faba bean, and the harvested area for this crop has increased by $74 \%$ over the last five years, estimated at 5,643 ha producing almost 16,000 tons (ELSTAT, 2018). Multi-environment field studies concerning faba bean germplasm adapted to local growing conditions are virtually absent. Therefore, the aim of this study was to determine the response of faba bean new inbred lines and cultivars to different environmental conditions during the 2018-2019 growing season.

\section{Materials and Methods}

Field experiments were carried out at three sites during the 2018-2019 growing season at Northern (Thermi, $40^{\circ} 32^{\prime} \mathrm{N}, 22^{\circ} 59^{\prime} \mathrm{E}, 5 \mathrm{~m}$ above sea level), Central (Larissa, $39^{\circ} 36^{\prime} \mathrm{N}, 22^{\circ} 25^{\prime} \mathrm{E}$, $77 \mathrm{~m}$ a.s.l.) and Southern Greece (Spata, 37 ${ }^{\circ} 58^{\prime}$ $\mathrm{N}, 23^{\circ} 54^{\prime} \mathrm{E}, 123 \mathrm{~m}$ a.s.l), experimental stations. The soil properties for the experimental sites are presented in Table 1.

Table 1. Physical and chemical properties of the soil at the experimental sites

\begin{tabular}{|c|c|c|c|}
\hline & North Thermi & Central Larissa & South Spata \\
\hline Texture class & Clay Loam & Clay & Sandy Clay Loam \\
\hline Sand \% & 25 & 20 & 50 \\
\hline Silt \% & 48 & 23 & 24 \\
\hline Clay \% & 27 & 57 & 26 \\
\hline $\mathrm{pH}$ & 7.7 & 8.0 & 7.9 \\
\hline Organic matter $\%$ & 1.24 & 1.30 & 1.43 \\
\hline $\mathrm{N}-\mathrm{NO}_{3}\left(\mathrm{mg} \mathrm{kg}^{-1}\right)$ & 38 & 10 & 15 \\
\hline P-Olsen $\left(\mathrm{mg} \mathrm{kg}^{-1}\right)$ & 29 & 14 & 59 \\
\hline $\mathrm{K}$ exchangeable $\left(\mathrm{mg} \mathrm{kg}^{-1}\right.$ ) & 157 & 131 & 138 \\
\hline $\mathrm{CaCO}_{3}$ & 3.5 & 1.8 & 3.9 \\
\hline
\end{tabular}


Weather data (rainfall, maximum and minimum air temperatures) were recorded daily and are reported as mean monthly data for the different experimental locations (Fig. 1. a, b, c). The experimental design was a randomized complete block (RCB) design with six small seeded cultivars [four inbred lines (KK18, KK101, KK10,
KK14) and two commercial cultivars ('Polycarpe' and 'Tanagra')] replicated four times. The plot size of each replication was $4.5 \mathrm{~m} \times 3 \mathrm{~m}$ and the experimental plots were $0.75 \mathrm{~m} \times 3 \mathrm{~m}$ and consisted of 3 rows $0.25 \mathrm{~m}$ apart. Sowing was performed on 18 November, 5 December and 4 February in Central, North and South Greece

a)

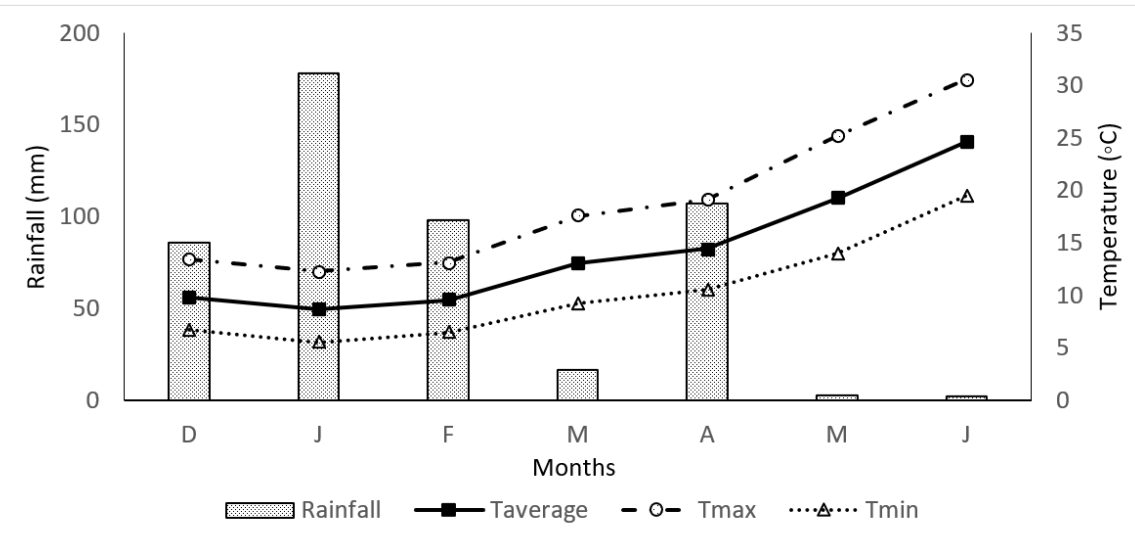

b)

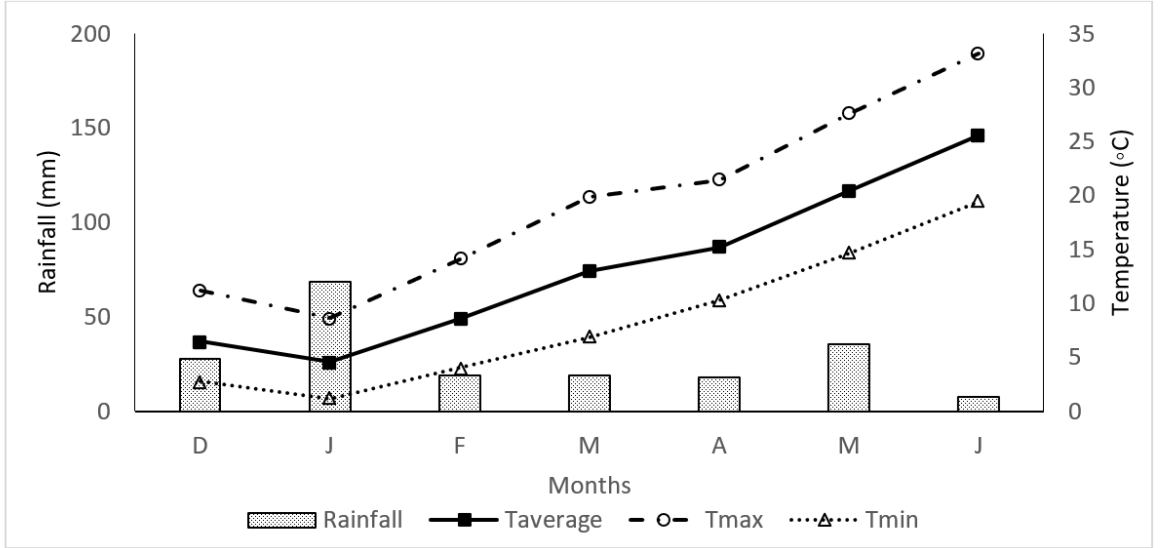

c)

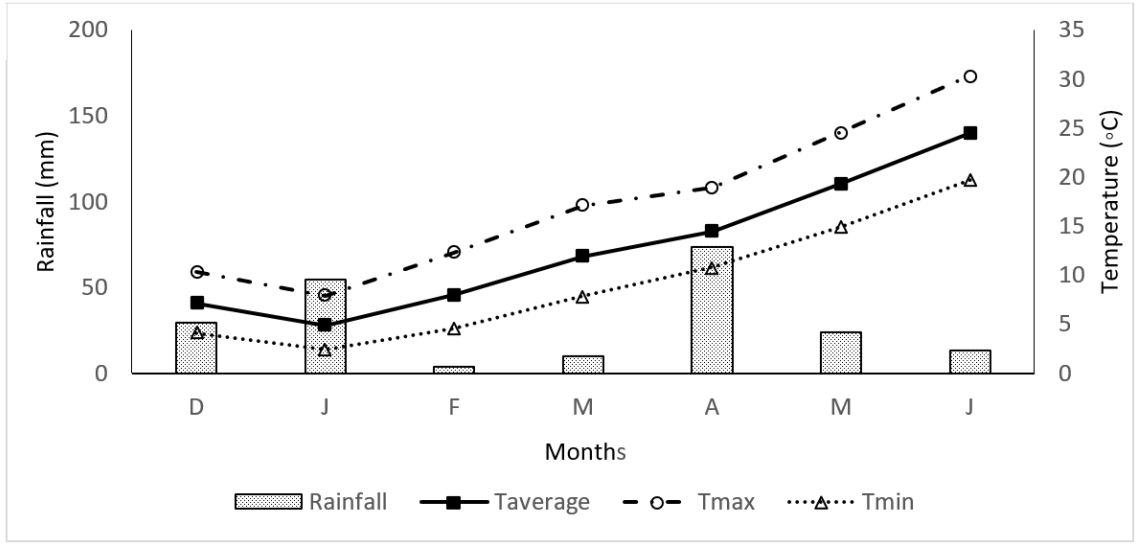

Figure 1. Monthly rainfall ( $\mathrm{mm}$ ) and temperatures (max, $\min$ and mean values; ${ }^{\circ} \mathrm{C}$ ) in the experimental sites a) Southern Greece (Spata), b) Central Greece (Larissa) and

c) Northern Greece (Thermi) during the growing period of the experimentation 
Table 2. Summary of seasonal temperature (1 Dec.-31 May) and rainfall at flowering and pod set stage (15 April-31 May)

\begin{tabular}{cccc}
\hline Location & Rainfall $(\mathrm{mm})$ & $\begin{array}{c}\text { Number of days with } \\
\text { min temperature }<0\end{array}$ & $\begin{array}{c}\text { Number of days with } \\
\text { max temperature }<27\end{array}$ \\
\hline North Greece (Thermi) & 11.8 & 7 & 5 \\
\hline Central Greece (Larissa) & 40.2 & 18 & 22 \\
\hline South Greece (Spata) & 2.8 & 3 & 10 \\
\hline
\end{tabular}

respectively, by hand at $3 \mathrm{~cm}$ depth in order to achieve the planned crop density of 48-50 plants $\mathrm{m}^{-2}$. Before sowing, $150 \mathrm{~kg} \mathrm{ha}^{-1}$ of an inorganic $\mathrm{P}$ fertilizer ( $\mathrm{N}: \mathrm{P}_{2} \mathrm{O}_{5}: \mathrm{K}_{2} 0$ ratio 0-46-0) were applied in the plots and the crop was kept free of weeds by hand hoeing.

Heights of five randomly selected plants per plot were measured from the base to the tip of the plant with the help of measuring tape at pod development stage (BBCH code 75, Lancashire et al., 1991). For seed yield data, samples from $3 \times$ $1 \mathrm{~m}$ cuts in central rows (edges were excluded) were harvested dried, threshed, cleaned, weighed and converted into seed yield $\left(\mathrm{kg} \mathrm{ha}^{-1}\right)$. To record number of pods per plant and seeds per pod data, five plants were randomly selected from the middle row of the experimental plots, their pods were taken, number of seeds counted and their average calculated. Thousand seed weight was measured for 2 samples of 100 randomly chosen seeds in each replication. For the statistical analysis SigmaPlot 12 statistical software (Systat Software Inc., San Jose, CA, USA) was used. Values were compared by analysis of variance (ANOVA) and Fisher's protected least significant difference at $5 \%$ level of probability (LSD 0.05 ) was used to compare the main effect and interaction means.

\section{Results and Discussion}

In general, the climate in Greece is Mediterranean, characterized as semiarid with winter precipitation, cool winter and hot summer. Weather conditions during the experimental season differed substantially between the three locations (Fig. 1. a, b, c).

The southern site (Spata) was warmer during winter, while the maximum temperatures were higher during spring and early summer at Larissa. Rainfall in the northern site (Thermi) was higher compared to the central experimental station at Larissa (210 $\mathrm{mm}$ and $196 \mathrm{~mm}$ respectively), while on both sites the lower values occurred in February and March. Above-normal rainfall occurred in Spata, especially in January, February and April (491 $\mathrm{mm}$ in total and $486 \mathrm{~mm}$ before flowering) compared to the long-term average (246 mm) between 1988-2018.

The combined analysis of variance showed that cultivars (C), locations (L) and their interaction $(\mathrm{L} \times \mathrm{C})$ had significant effects on seed yield $(P<0.05)$, plant height, number of pods per plant, number of seeds per pods and thousand seed weight $(P<0.001)$ (Tab. 3). Higher plant height values were recorded in Larissa for all cultivars and lower values were observed in the other two locations (Thermi and Spata). Lines KK10 and KK14 had taller plants on all sites. In addition, the inbred line KK101 showed greater winter mortality in Thermi (therefore height and seed yield data were not presented), while in Larissa this trend has not been verified, suggesting higher winter survival even though absolute minimum temperatures below $0^{\circ} \mathrm{C}$ for 18 days were recorded in this location (Tab. 2). Comparable results were reported by Annicchiarico and Iannucci (2008) who found that mild winter temperatures prevented a sufficient hardening against frost conditions. Winter hardiness of winter sown faba bean cultivars is dependent on frost tolerance and hardening, and influenced by diseases, snow cover, sowing date and waterlogging (Link et al., 2010; Neugschwandtner et al., 2019). The northern location Thermi was a higher yielding environment for number of pods per plant and number of seed per pod (27.8 and 4 averaging over cultivars respectively) than the central location Larissa (12.1 and 2.97 accordingly). The warmer conditions during flowering and pod development at Larissa increased flower abortion and pod shedding compared to the more favorable cooler temperatures at Thermi (Tab. 2). Previous researches have revealed that when the 


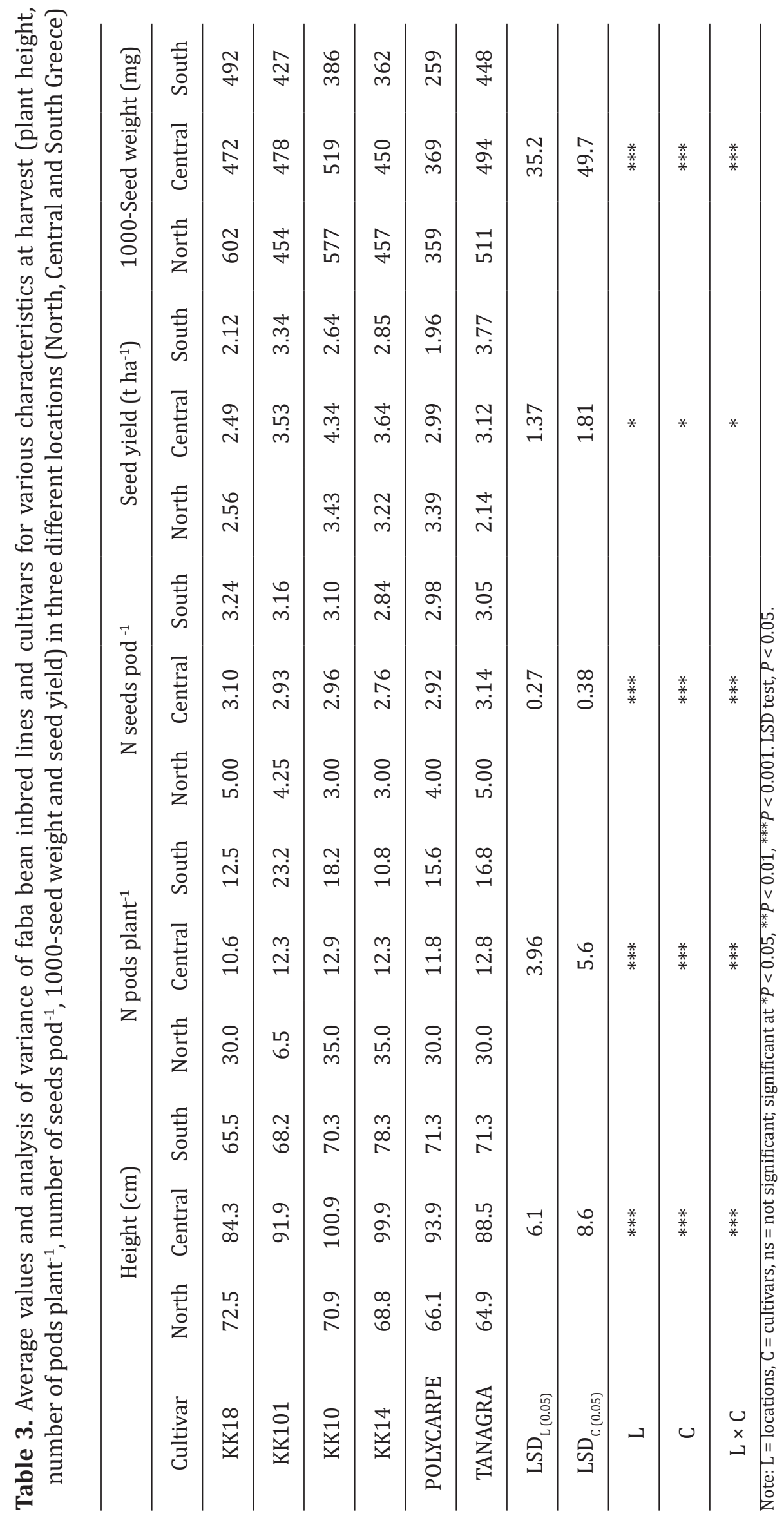


temperature increased by 1.5 to $2.0^{\circ} \mathrm{C}$ pods per plant and seeds per pod decreased significantly (Bishop et al., 2016; Guoju et al., 2017; Manning et al., 2020). Despite reduced production of pods and seeds observed in Larissa the higher rainfall amounts in April and May led to higher 1000seed weight values and resulted in higher yields (Tab. 2, Tab. 3, Fig. 1). In addition, the southern location, Spata, showed reduced values for 1000 seed weight and seed yield (396 g and $2.78 \mathrm{t} \mathrm{ha}^{-1}$ averaging over cultivars) than the other two sites caused mainly by water shortage during May (Tab. 2).

Drought at early podding developmental stage was the most sensitive to water deficit in faba beans, causing a reduction in harvest indices and seed yields of at least 50\% (Abid et al., 2017; Migdadi et al., 2016; Mwanamwenge et al., 1999; Siddiqui et al., 2015). The late maturity cultivar 'Polycarpe' and line KK14 performed poorly and produced lower seed yields especially in the southern site Spata (Tab. 3). Similar results were obtained in previous studies which found that the late maturity cultivars showed greater susceptibility to drought stress at early pod development stage and the shorter maturity genotypes allowed seed to fill before exposure to terminal drought stress, which agrees with the known conception that early flowering is considered an important adaptation trait for coolseason legumes growing under Mediterranean semi-arid conditions (Annicchiarico and Iannucci 2008; Etemadi et al., 2018; Khan et al., 2010; Manning et al., 2020; Mwanamwenge et al., 1998).

\section{Conclusion}

In general, the results of this study showed that the environmental conditions had significant effect on faba bean plant characteristics and yield components. Lower temperatures below zero at the vegetative stage, and water stress accompanied by heat at the reproductive phase negatively affect plant growth and yield. Faba bean genotypes exhibited considerable variability for yield components between environments with contrasting results. Multi-location trials are useful for the evaluation of new top-yielding cultivars across environments and can thus lead to an increase in production of feedstuff directly available to farmers.

\section{References}

1. Abid G, Hessini K, Aouida M, Aroua I, Baudoin JP, Muhovski Y, Mergeai G, Sassi K, Machraoui M, Souissi F, Jebara M (2017). Agro-physiological and biochemical responses of faba bean (Vicia faba L. var. 'minor') genotypes to water deficit stress. Biotechnol. Agron. Soc. Environ., 21(2): $1-14$.

2. Annicchiarico P, Iannucci A (2007). Winter survival of pea, faba bean and white lupin cultivars in contrasting Italian locations and sowing times, and implications for selection. J. Agric Sci., 145: 611-622.

3. Annicchiarico P, Iannucci A (2008). Breeding strategy for faba bean in southern Europe based on cultivar responses across climatically contrasting environments. Crop Sci., 48: 983-991.

4. Bishop J, Potts SG, Jones HE (2016). Susceptibility of faba bean (Vicia faba L.) to heat stress during floral development and anthesis. J. Agron. Crop Sci., 202: 508517.

5. Crépon K, Marget P, Peyronnet C, Carrouée B, Arese P, Duc G (2010). Nutritional value of faba bean (Vicia faba L.) seeds for feed and food. Field Crops Res., 115: 329-339.

6. De Ron A, Sparvoli F, Pueyo JJ, Bazile D (2017). Protein crops: Food and feed for the future. Front. Plant Sci., 8: 105.

7. ELSTAT (2018). Hellenic Statistical Authority Statistics Agriculture, Livestock and Fishery. http://www.statistics. gr/en/statistics.

8. Etemadi F, Hashemi M, Zandvakili O, Mangan FX (2018). Phenology, yield and growth pattern of faba bean varieties. Int. J. Plant Prod., 12: 243-250.

9. EUROSTAT (2018). European Commission, Brussels, Belgium.

10. FAOSTAT (2018). Food and Agricultural Organization of the United Nations. Statistics Database.

11. Guoju X, Qiang Z, Jing W, Fengju Z, Chengke L, Fei M, Juying H, Ming L, Xianping H, Zhengji Q (2017). Influence of increased temperature on the yield and quality of broad bean in semiarid regions of northwest China. Plant Soil Environ., 63(5): 220-225.

12. Khan HR, Paull JG, Siddique KHM, Stoddard FL (2010). Faba bean breeding foe drought-affected environments: A physiological and agronomic perspective. Field Crops Res., 115: 279-286.

13. Karkanis A, Ntatsi G, Lepse L, Fernández JA, V ågen IM, Rewald B, Alsing I, Kronberga A, Balliu A, Olle M, Bodner G, Dubova L, Rosa E, Savvas D (2018). Faba bean cultivation Revealing novel managing practices for more sustainable and competitive European cropping systems. Front. Plant Sci., 9: 1115.

14. Lancashire PD, Bleiholder $H$, Van Den Boom $T$, Langelüddeke P, Stauss R, Weber E, Witzenberger A (1991). A uniform decimal code for growth stages of crops and weeds. Ann. App. Biol., 119: 561-601.

15. Link W, Balko C, Stoddard FL (2010). Winter hardiness in faba bean: Physiology and breeding. Field Crops Res., 115: 287-296. 
16. Manning BK, Adhikari KN, Trethowan R (2020). Impact of sowing time, genotype, environment and maturity on biomass and yield components in faba bean (Vicia faba). Crop Pasture Sci., 71:147-154.

17. Migdadi HM, El-Harty EH, Salamh A, Khan MA (2016) Yield and proline content of faba bean genotypes under water stress treatments. J. Anim. Plant Sci., 26(6): 17721779.

18. Mwanamwenge J, Loss SP, Siddique KHM, Cocks PS (1998). Growth, seed yield and water use of faba bean (Vicia faba L.) in a short-season Mediterranean-type environment. Aust. J. Exp. Agric., 38: 171-180.

19. Mwanamwenge J, Loss SP, Siddique KHM, Cocks PS (1999). Effect of water stress during floral initiation, flowering and podding on the growth and yield of faba bean (Vicia faba L.). Eur. J. Agron., 11: 1-11.

20. Neugschwandtner RW, Ziegler K, Kriegner S, Wagentristl H, Kaul HP (2015). Nitrogen yield and nitrogen fixation of winter faba beans. Acta Agr. Scand B Soil Plant Sci., 65: 658-666.

21. Neugschwandtner RW, Bernhuber A, Kammlander S, Wagentristl H, Klimek-Kopyra A, Kaul HP (2019).
Agronomic potential of winter grain legumes for Central Europe: Development, soil coverage and yields. Field Crops Res., 241: 107576.

22. Robson MC, Fowler SM, Lampkin NH, Leifert C, Leitch M, Robinson D, Watson CA, Litterick AM (2002). The agronomic and economic potential of break crops for ley/ arable rotations in temperate organic agriculture. Adv. Agron., 77: 369-427.

23. Siddiqui MH, Al-Khaishany MY, Al-Qutami MA, Al-Whaibi MH, Grover A, Ali HM, Wahibi MS, Bukhari NA (2015). Response of different genotypes of faba bean plant to drought stress. Int. J. Mol. Sci., 16: 10214-10227.

24. Squire GR, Quesada N, Begg GS, Iannetta PPM (2019). Transitions to greater legume inclusion in cropland: Defining opportunities and estimating benefits for the nitrogen economy. Food Energy Secur., 8(4) e00175.

25. Watson CA, Reckling M, Preissel S, Bachinger J, Bergkvist G, Kuhlman T, Lindström K, Nemecek T, Topp CFE, Vanhatalo A, Zander P, Murphy-Bokern D, Stoddard FL (2017). Grain legume production and use in European agricultural systems. Adv. Agron., 144: 235-301. 